\title{
No-tillage sorghum and garbanzo yields match or exceed standard tillage yields
}

\author{
Results from a 4-year trial indicate that garbanzo and sorghum yields under no-tillage practices \\ were similar to or higher than those under standard tillage.
}

by Jeffrey P. Mitchell, Anil Shrestha, Lynn Epstein, Jeffery A. Dahlberg, Teamrat Ghezzehei, Samuel Araya, Brian Richter, Sukhwinder Kaur, Peter Henry, Daniel S. Munk, Sarah Light, Monte Bottens and Daniele Zaccaria

Online: https://doi.org/10.3733/ca.2021a0017

\section{Abstract}

To meet the requirements of California's Sustainable Groundwater Management Act, there is a critical need for crop production strategies with less reliance on irrigation from surface and groundwater sources. One strategy for improving agricultural water use efficiency is reducing tillage and maintaining residues on the soil surface. We evaluated high residue no-till versus standard tillage in the San Joaquin Valley with and without cover crops on the yields of two crops, garbanzo and sorghum, for 4 years. The no-till treatment had no primary or secondary tillage. Sorghum yields were similar in no-till and standard tillage systems while no-till garbanzo yields matched or exceeded those of standard tillage, depending on the year. Cover crops had no effect on crop yields. Soil cover was highest under the no-till with cover crop system, averaging $97 \%$ versus 5\% for the standard tillage without cover crop system. Our results suggest that garbanzos and sorghum can be grown under no-till practices in the San Joaquin Valley without loss of yield. ince the advent of irrigation in California with the widespread drilling of wells in the 1930s, several public policy changes affecting surface water allocations, and the proliferation of orchard and vineyard crops during the past two decades, have resulted in total annual water requirements in many irrigation districts exceeding surface water supplies and reliance on groundwater use to make up for the difference, especially during the recent drought. Partly as a consequence, California enacted the Sustainable Groundwater Management Act (SGMA) in 2014 (DWR 2014), which in time will limit withdrawals to sustainable groundwater extractions. Because irrigated agriculture accounts for $40 \%$ of all available water supplies, but up to $80 \%$ of developed water supplies, especially in the San Joaquin Valley (SJV) (DWR 2018), groundwater use will be restricted in this region to meet the requirements of SGMA. This will have significant economic consequences. With some climate change projections suggesting a potential $20 \%$ water availability loss by the middle of the century in California due to global warming (Udall and Overpeck 2017), there is a critical need for strategies with less reliance on irrigation from surface and groundwater sources in crop production.

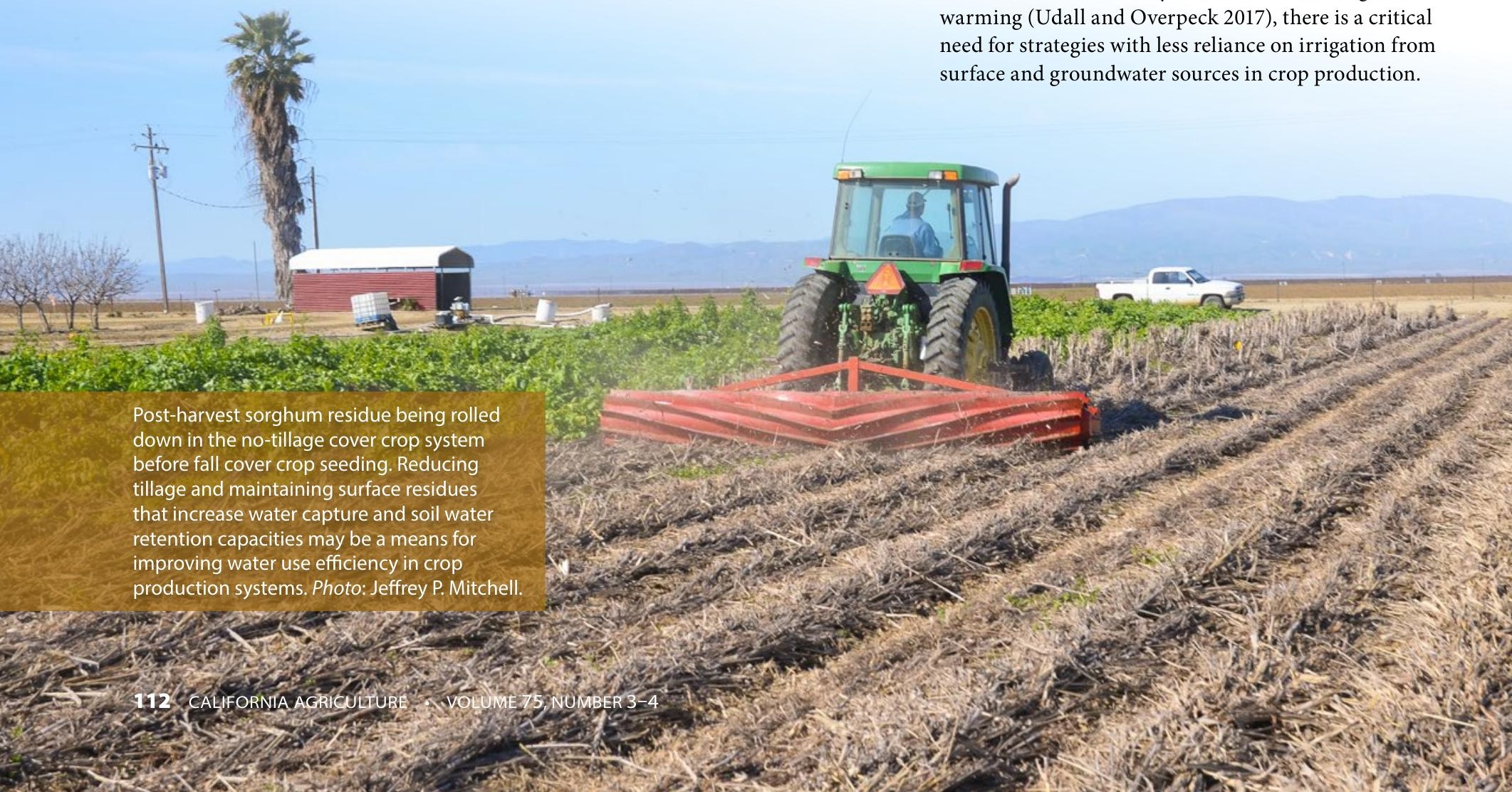


Reducing tillage (the physical manipulation of the soil using operations such as plowing, disking and subsoil ripping) in the context of conservation agriculture (see sidebar) offers a currently under-utilized strategy for improving agricultural water use efficiency in California (Bettner 2012; Mitchell et al. 2019).

Decreasing soil water evaporation relative to total evapotranspiration (ET) by reducing tillage and maintaining surface residues that increase water capture and soil water retention capacities may be a means for improving water use efficiency in crop production systems. This has been demonstrated under both irrigated (Klocke et al. 2009; van Donk et al. 2020) and rain-fed conditions (Unger 1984; Unger and Baumhardt 1999; Unger and Parker 1976). Crop residues (plant and cover crop material remaining after harvest) reduce evaporation and water loss from wet soils by shading (reducing soil surface temperatures) and by reducing wind erosion effects (Klocke et al. 2009; van Donk et al. 2010). Several studies from both irrigated and rain-fed regions around the United States (some of which also use supplemental irrigation) where no-tillage (NT) is used have reported annual water savings by as much as 4 to 5 inches (Klocke et al. 2009) in crop production systems that typically have 23 to 25 inches of seasonal crop ET (F. Lamm, Kansas State University, personal communication). At Kansas State University's Southwest Research and Extension Center in Garden City, Kan., full-surface residue coverage with corn stover and wheat stubble reduced evaporation by $50 \%$ to $65 \%$ compared to bare soil with no shading (Klocke et al. 2009). Research in Nebraska showed that tillage operations before planting can dry the soil in the tillage layer with a loss of 0.3 to 0.75 inches of soil moisture per tillage pass (Pryor 2004) in overhead sprinkler irrigated systems. Compared to conventional tillage under overhead irrigation, switching to NT has also been shown to save 3 to 5 inches of water annually with an added savings of $\$ 14$ to $\$ 23$ per acre in 2004 US $\$$ from pumping costs (Pryor 2004) in Nebraska.

Several dryland regions around the world are also adopting NT to diversify and intensify annual crop production. In the Canadian prairies, NT enhanced soil health, increased soil water availability in nearsurface layers, and allowed the introduction of new crops, including oilseeds and legumes (Lindwall and Sonntag 2010). As a result, the planted area under NT has increased from 5\% in 1991 to over 80\% in 2011, thus reducing reliance on the traditional summer fallow. In the U.S. central Great Plains, NT has benefited agricultural management and local farm economies by permitting both the intensification and diversification of cropping systems. For example, cropping in this area, sometimes in places with only 15 inches of annual rainfall, has changed from one crop every other year, to two crops every 3 years, to cropping every year (Anderson 2011). NT has also been extensively adopted for cereal production in the southwestern Australia drylands, an area with only about 10 inches of annual

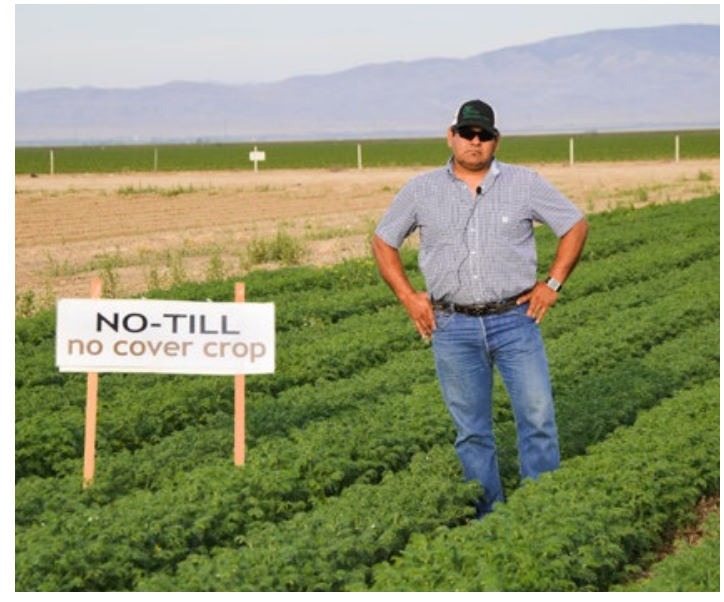

UC Westside Research and Extension Center Superintendent Rafael Solorio stands in a no-tillage no cover crop (NTNO) garbanzo plot. Photo: Jeffrey P. Mitchell.

\section{Definition of conservation agriculture}

A Ithough currently not widely used in much of California's annual cropland, the core principles and concepts of what are widely and particularly internationally regarded as conservation agriculture (CA) systems may provide an important unifying framework for the development of improved performance crop production systems in the future. CA has three linked principles:

- Continuous minimum mechanical soil disturbance

- Preservation of residues that provide permanent soil cover

- Diversification of crop rotations and emphasis on soil biodiversity

CA is more than avoidance of tillage. It is a farming system that involves changes in cultural practices along with a change in approach that bypasses the use of intense tillage disturbance, focuses on improving soil function, and increases the efficiency of water, energy and nutrient cycling (Mitchell et al. 2019). CA also emphasizes carbon management by focusing on extending the period of crop and residue cover on the soil.

We envision expanded application of CA principles in a variety of California's annual cropping systems for forage and grain, energy, fiber and vegetables as production techniques are further refined. The Conservation Agriculture Systems Innovation (CASl; http://casi.ucanr.edu/) Center works to develop information on locally relevant adaptations of CA systems that include the use of cover crops, integrated pest management, precision irrigation and controlled or limited mechanical traffic on soil and is a resource for farmers interested in learning more about the use of these techniques in California.

rainfall and no irrigation options, which is similar to a sizable portion of the SJV (Ward et al. 2012), where the benefits of surface residues include moisture retention during germination and early growth of the subsequent crop (K. Flower, University of Western Australia, personal communication).

NT and residue preservation have additional benefits, including lower soil temperatures during the summer (Mitchell et al. 2012) and higher water retention (Mitchell et al. 2019; Sposito 2013), increased soil water capture from improved infiltration and retention, 
TABLE 1. Measured changes in soil properties and functions in the NRI Project system soils (1999-2018)

\begin{tabular}{|l|l|l|}
\hline Soil property or function & $\begin{array}{c}\text { Direction of effect } \\
\text { resulting from NT } \\
\text { and cover crops }\end{array}$ & Reference \\
\hline Soil carbon and nitrogen & + & Mitchell et al. 2017 \\
\hline Soil water infiltration & + & Mitchell et al. 2017 \\
\hline Soil aggregate stability & + & Mitchell et al. 2017 \\
\hline Nematode abundance & + & Zhang et al. 2017 \\
\hline Soil macrofauna diversity & + & Kelly et al. 2021 \\
\hline
\end{tabular}
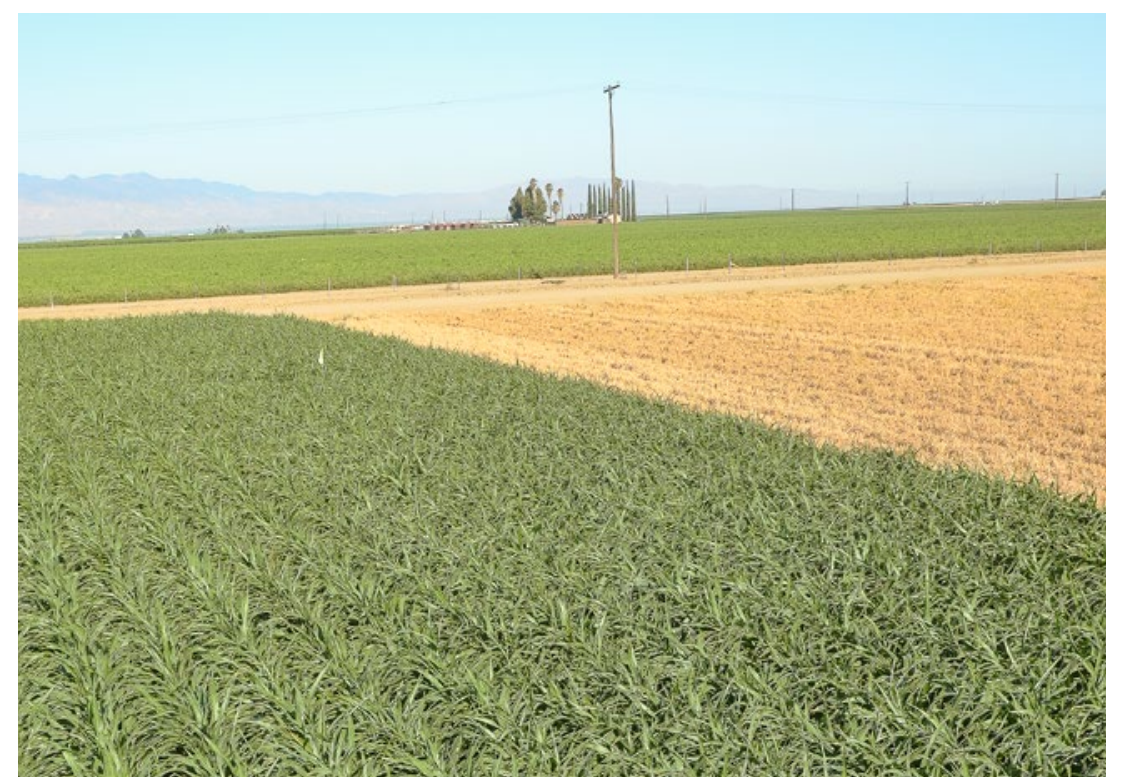

Experimental no-tillage plots at the UC West Side Research and Extension Center, Five Points, Calif., with sorghum (foreground) and garbanzo stubble (top right). Photo: Jeffrey P. Mitchell.

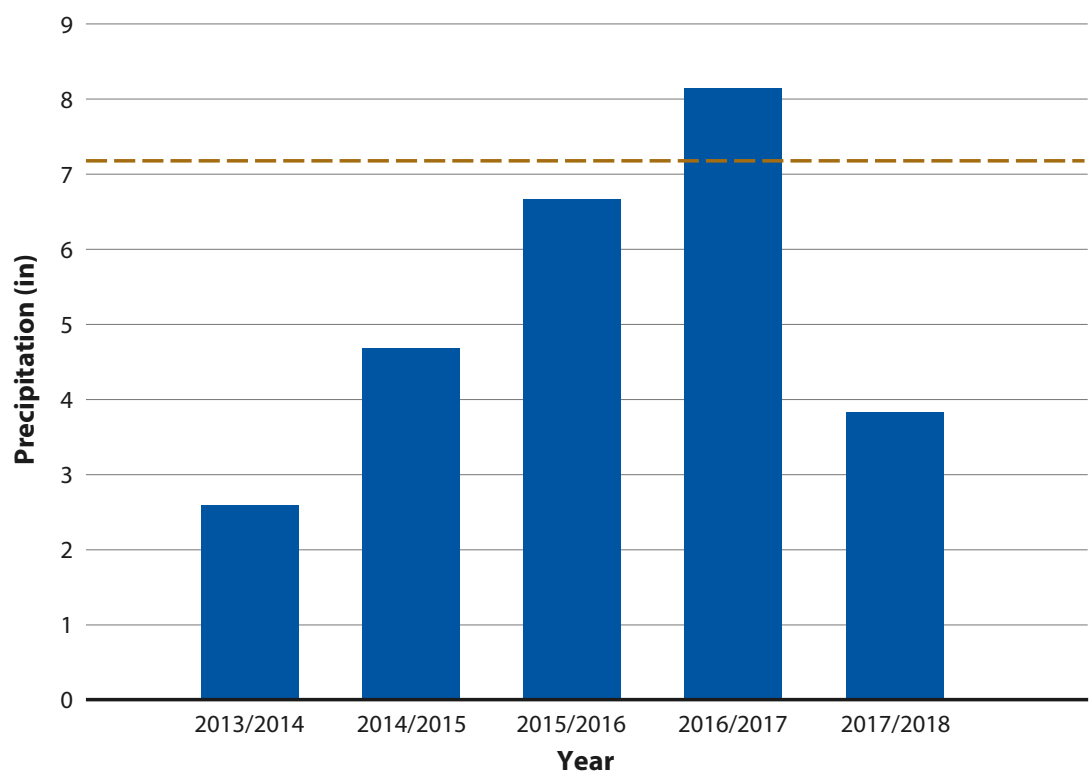

FIG.1. Total annual precipitation (2014-2018) and the 30-year average (represented by the dotted line) at the UC West Side Research and Extension Center in Five Points, Calif. increased water storage capacity from increased organic matter and changes in pore size distribution (Franzluebbers 2010) for all texture groups (Berman 1994), increased carbon and nitrogen storage (Mitchell at al. 2017) and increased biological activity (Schmidt et al. 2018; Zhang et al. 2018) (table 1). Cost savings of $\$ 50$ to $\$ 150$ per acre for a variety of crops in the SJV from NT have been documented (Mitchell et al. 2016; Mitchell, Shrestha, Munk 2016). Compared to ST, NT uses less diesel fuel and requires less labor (Mitchell et al. 2008), and generates less dust (Baker et al. 2005; Madden et al. 2008). Sustained NT coupled with cover crops (CCs) has also been shown to increase soil aggregation, water infiltration and biological diversity compared to ST after 18 years of the practices on a clay loam soil. Generalizing from Mitchell et al. (2012), about 13\% (4 inches), of soil water loss from evaporation in a summer crop using 30 acre-inches of water in the SJV could potentially be avoided if reduced disturbance, residuepreserving practices are used on soils with overhead or surface furrow or flood irrigation.

We evaluated the potential for producing sorghum and garbanzo beans - two crops that might be amenable to NT in the SJV - using high residue NT techniques. Sorghum is the fifth most important cereal crop in the world (FAOSTAT 2019). The United States, led by Kansas and Texas, is the world's largest sorghum producer with $16 \%$ of the world's production. In California, there is renewed interest in sorghum as a potential replacement for silage corn because of its drought tolerance. Approximately $20 \%$ of U.S. sorghum is produced using NT or strip-tillage, a tillage management system that only disturbs the portion of the soil where the seed row will be; however, these practices are uncommon in California and very little is known about their potential locally. Garbanzo beans are a winter planted crop that are grown on about 10,000 acres for the canning industry (CDFA 2018). Garbanzo seed size is similar to soybean, which is NT-planted in several parts of the United States and on over 75\% of acreage in Brazil, Argentina and Paraguay.

\section{Study site and tillage systems}

In these experiments, we compared grain sorghum and garbanzo yields under NT with no cover crop (NTNO) or with cover crops (NTCC) versus ST with no cover crops (STNO) or with cover crops (STCC). The 8.8acre study site was in the National Research Initiative (NRI) Project at the University of California's West Side Research and Extension Center (WSREC), Five Points, Calif. $\left(36^{\circ} 20^{\prime} 29^{\prime \prime} \mathrm{N}, 120^{\circ} 7^{\prime} 14^{\prime \prime} \mathrm{W}\right)$. The soil type is a Panoche clay loam, which is a very deep, well-drained soil on alluvial fans. Average annual precipitation is about 8.2 inches (fig. 1). Treatments included a factorial arrangement of tillage and CC in a randomized complete block design with four replications. Each plot was 29.9 feet by 270 feet and consisted of six 5 -foot beds.

ST consisted of conventional intercrop tillage 
operations of residue shredding, multiple diskings to incorporate residues, subsoiling to a depth of about 18 inches in the bed shoulder areas to avoid damaging the buried drip tape that was in the center of beds at about 8 inches deep, additional disking to break up soil clods and for the shaping of beds, and incorporation of the surface soil using a cultimulcher (BW Implement, Buttonwillow, Calif.), which is a PTO (power take-off)powered aggressive tillage operation that pulverized the top 8 inches of soil into a fine, powdery seedbed for both the STNO and STCC systems. These conventional intercrop tillage practices break down and establish new beds following harvest and represent normal operations in the SJV in terms of the intensity, depth and timing of tillage (Mitchell et al. 2017).

The only soil disturbance in the NT systems occurred during seeding and fertilizing in prior years when tomatoes were grown, during shallow cultivations for weed management and for the one-time installation of drip tape in 2012. The tillage and CC treatments were maintained in the same plots during the study. To have both crops in each year, a garbanzo/ sorghum rotation was used on half of the plots and a sorghum/garbanzo crop sequence was used on the other half of the plots.

In the CC plots, a mix of triticale (Triticosecale Wittm.), cereal rye (Secale cereale L.), common vetch (Vicia sativa), radish (Raphanus sativus) and clover (Trifolium incarnatum) was seeded in 7.5-inch rows at 80 pounds per acre $(\mathrm{lb} / \mathrm{ac})$ in late October or early November at 20,20,30, 5 and $5 \mathrm{lb}$, respectively. The CCs were not irrigated in the fall of 2013, 2014 or 2015, but received 2 inches of sprinkler irrigation in 2016. In late March of the following year, the CC was cut at the soil line with a stalk chopper and the residue sprayed with $2 \%$ glyphosate and left on the surface as a mulch. In the ST system, the residue was disked into the soil. A 0.9 -inch diameter drip tape with emitters every 13.8 inches and a flow rate of 0.16 gallons per hour was installed 12 inches deep and 60 inches apart (Netafim Streamline 875 0135F, Netafim USA, Fresno, Calif.) in all plots.

Dry fertilizer (11-52-00) was shank-applied to both crops at $200 \mathrm{lb} / \mathrm{ac}$ pre-plant. For weed control, in the sorghum plots, Dual Magnum (S-metolachlor) (24 ounces per acre [oz/ac]) and Clarity (Dicamba diglycolamine salt) at $8 \mathrm{oz} / \mathrm{ac}$ were applied pre-plant and postestablishment, respectively, while in the garbanzo plots, Prowl H2O (Pendimethalin) $(20 \mathrm{oz} / \mathrm{ac})$ and Chateau (Flumioxazin) (2 oz/ac), were applied post planting, pre-crop and pre-weed emergence for weed control. These materials were all spray-applied and incorporated using sprinkler irrigation.

The grain sorghum hybrids NK7829 (2014), 251 (2015) and K5585 (2016 and 2017) (Sorghum Partners, New Deal, Texas) were seeded on May 7, 2014, May 11, 2015, May 20, 2016, and May 22, 2017, respectively, using a John Deere 1730 six-row NT planter at 72,870 seeds/ac or about 4 seeds per foot of row. Garbanzo beans (AWF-1, 2015 and 2016, and UC27, 2017 and 2018) were inoculated with a crop-specific rhizobia bacteria and seeded using the same planter at 100,000 seeds/ac or about 5 seeds per foot of row on Feb. 5, 2015, Feb. 22, 2016, March 16, 2017, and March 9, 2018. Both crops were established with two sprinkler irrigations of 1 inch each.

Reference ET $\left(\mathrm{ET}_{\mathrm{o}}\right)$ and crop coefficient $\left(\mathrm{K}_{\mathrm{c}}\right)$ values were used to generate daily crop ET estimates to determine irrigation timing. $\mathrm{ET}_{\mathrm{o}}$ data were acquired from a California Irrigation Management Information System (CIMIS; www.cimis.water.ca.gov) weather station located about 200 yards from the study field. $\mathrm{K}_{\mathrm{c}}$ values were based on average crop canopy estimates of both crops (Hanson and May 2005; Hanson and May 2006). Irrigation frequency varied depending on ET demand

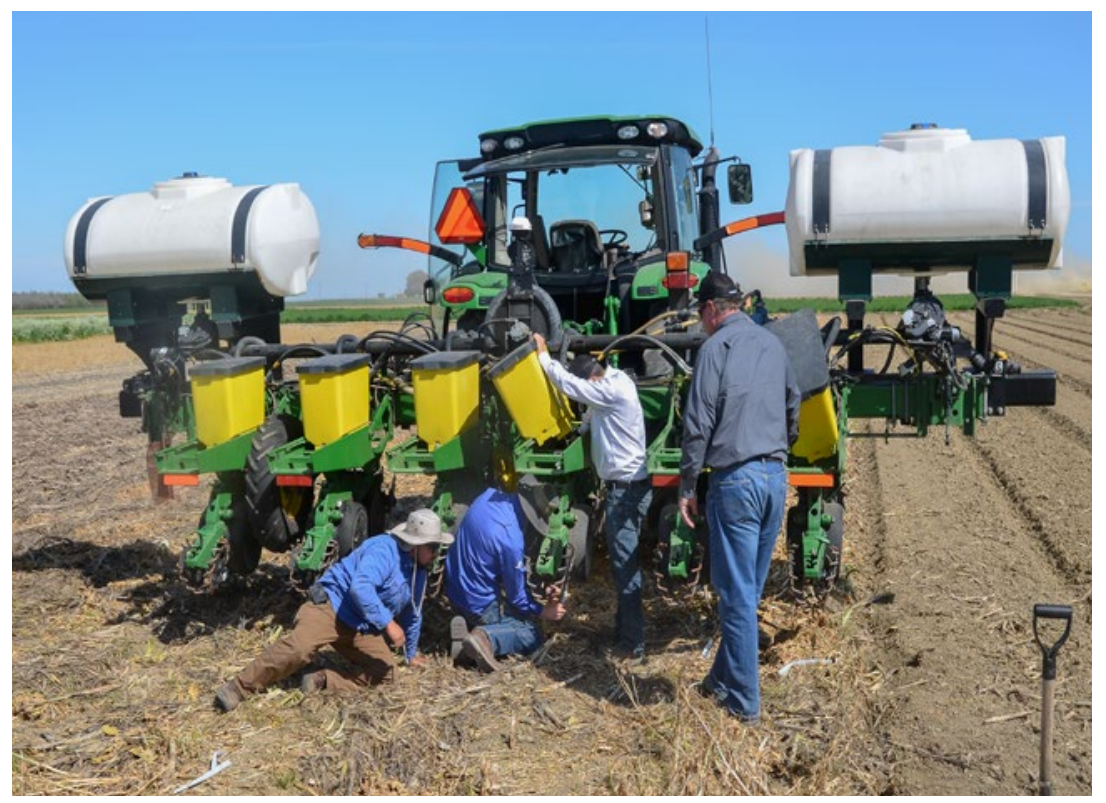

Research colleagues from California Ag Solutions, Madera, Calif., assist with John Deere 1730 no-tillage planter adjustments for garbanzo seeding. Photo: Jeffrey P. Mitchell.

conditions throughout the season but was typically two to three times per week. No precipitation occurred during any of the summer cropping seasons. Applied water amounts averaged about 20 inches for sorghum and 12 inches for garbanzo, which are close to historical estimates for crop evapotranspiration $\left(\mathrm{ET}_{\mathrm{c}}\right)$ and commercial application volumes in the region (Long et al. 2019; Steduto et al. 2012) and which are within the bounds of consumptive water use (ET) estimates for well-watered sorghum (Steduto et al. 2012). The same amount of water was applied to all treatments of a given crop in each year. Weekly fertigations (32-0-0) as urea ammonium nitrate were applied to the sorghum crop totaling 165, 166, 185 and $218 \mathrm{lb} / \mathrm{ac}$ material in 2014, 2015, 2016 and 2017, respectively. The garbanzo crops were all carefully inoculated with rhizobia each year. No fertigated nitrogen applications were made to the garbanzos as is the custom in commercial fields in the region.

Crop stands were estimated by counting the 


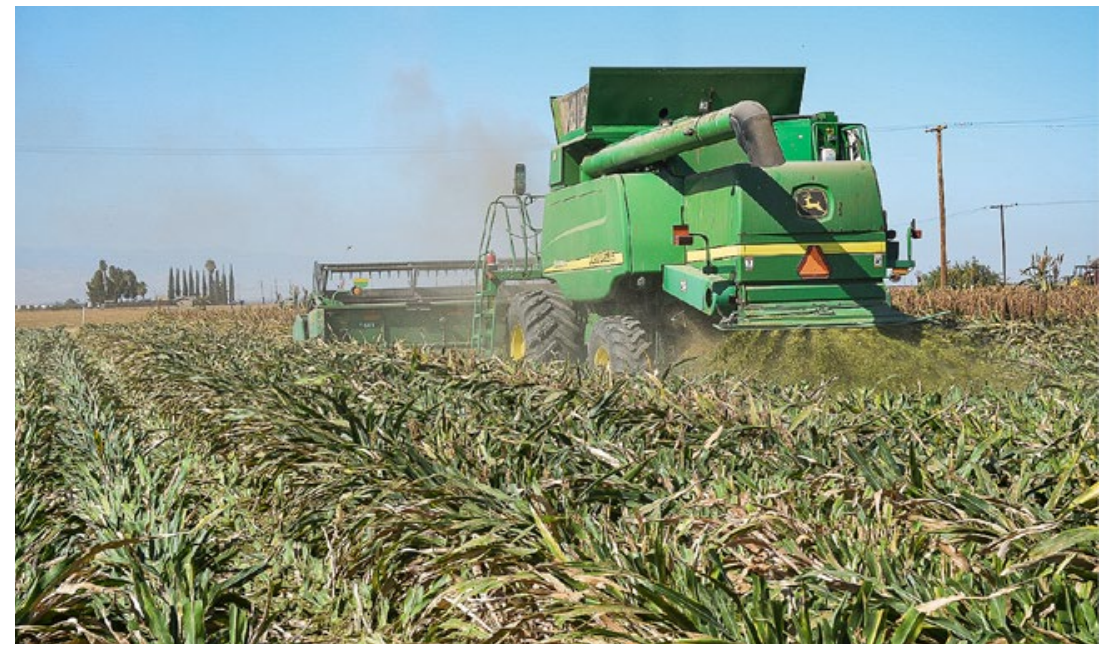

Thirty-foot wide combine harvester used for sorghum grain and garbanzo harvests. Photo: Jeffrey P. Mitchell.

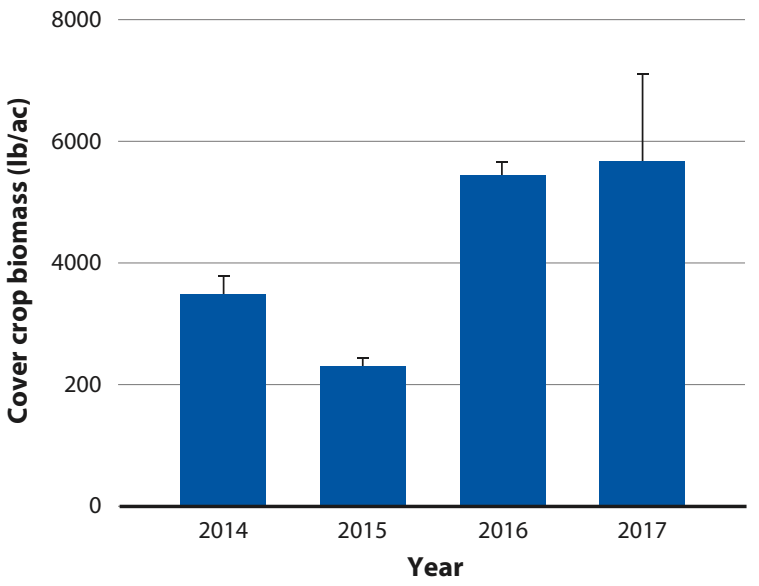

FIG. 2. Cover crop dry biomass (lb/ac) for cover crop systems 2014-2017.

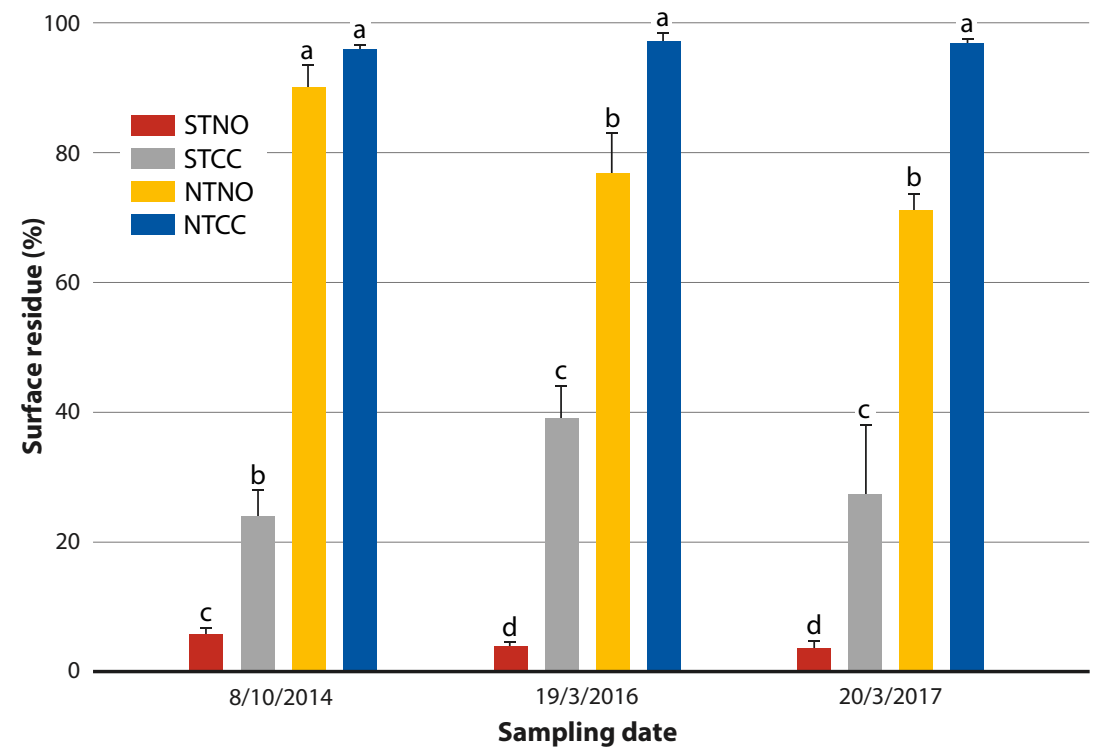

FIG. 3. Surface residue coverage (\%) on Aug. 10, 2014, March 16, 2016, and March 20, 2017, as averages. Error bars represent standard errors. Systems with different lowercase letters within a given date are significantly different $(P \leq 0.05)$. number of emerged seedlings along two 100-foot lines within a plot about 2 weeks after planting. Canopy cover, in both crops, was estimated by taking one image per plot using the Canopeo image-analyzing app for iPhones. Final grain yield of sorghum was determined by harvesting 49.2-foot lengths of one row in a representative area in each plot with an 18.1-inch bundle plot thresher (Kincaid Equipment Manufacturing, Haven, Kan.) in 2015 and by harvesting and weighing the grain from an entire plot using a John Deere combine in the other years.

Sorghum harvests were conducted on Oct. 14, Sept. 4, Oct. 12 and Oct. 16 in 2014, 2015, 2016 and 2017, respectively. Garbanzo yields were determined by harvesting the entire plots in all years using a combine. Harvests were done on July 20, July 22, July 28 and Aug. 15 in 2015, 2016, 2017 and 2018, respectively. After harvest and intercrop tillage on Aug. 10, 2014 (post crop harvest), March 19, 2016, and March 20, 2017 (post cover cropping), surface residue was estimated using the line-transect method, which involves counting the number of intersections with surface residue pieces every foot along a 100-foot transect. Data were analyzed using SAS version 9.3 (SAS Institute Inc., Cary, N.C.) using a significance level of 0.05 . The ANOVA model included year as a random effect, tillage type and CC system as fixed effects, and interaction between all combinations of year, tillage and CC. Yield data satisfied the assumptions (normality and homogeneity of variance) of ANOVA.

\section{CC biomass production}

Over the 5 years of the study that were characterized by recurring drought, a total of 8.4 tons of aboveground dry CC biomass (fig. 2) representing about $358 \mathrm{lb} / \mathrm{ac}$ nitrogen and 3.4 tons/ac carbon was produced with a total precipitation of 22 inches and 4 inches of supplemental irrigation in 2016 and 2017 to all plots (plus residual soil moisture following summer crops which is assumed to have been negligible). The CCs were typically seeded by Oct. 15 of each fall and terminated around Feb. 1 of the following spring for garbanzo and March 15 for sorghum, accounting for a growth period of 105 days before garbanzos and 120 days before sorghum. Compared to the systems with no CCs (NO), which were bare during this time, the CC treatments had an additional 90 days annually of actively growing green ground cover and living roots in the soil.

\section{NT increased surface residue coverage}

Both ST and CCs affected percentage surface residue (fig. 3). The NT systems had more surface residue than the ST systems and the CC plots had more residue than the no CC (NO) plots ( $97 \%$ for the NTCC, $82 \%$ for the NTNO, $30 \%$ for the STCC and $5 \%$ for the STNO across all sampling dates). Irrigation was 
provided as needed to all treatments in this trial and differences in soil water content were not measured. But previous work with other crops at the WSREC, work reported elsewhere (Unger and Parker 1976) and well-established micro-meteorological principles (T.C. Hsaio, Department of Hydrology, UC Davis, personal communication; Luo et al. 1992) suggest savings would be possible when irrigation water is limiting. Based on prior work at the WSREC (Mitchell et al. 2012) for a clay loam soil under sprinkler irrigation, approximately $13 \%$ (4 inches) of soil water loss from evaporation in a summer crop in the SJV was avoided when reduced disturbance residue-preserving practices were used. Similar responses should apply to all instances where NT management is followed for the production of warm season annual crops.

\section{Sorghum yields similar in NT and ST}

There were no significant interactions between year and tillage $(P=0.91)$, year and CC $(P=0.68)$, tillage and CC $(P=0.18)$ or year, tillage and CC $(P=0.53)$ on sorghum grain yield, but year was highly significant $(P<0.001)$. Averaged over the 4 years, the NT $(4,757 \pm 257 \mathrm{lb} / \mathrm{ac})$ and ST $(4,984 \pm 278 \mathrm{lb} / \mathrm{ac})$ had approximately similar yields. In analyses by year, there were no significant $(P>0.05)$ interactions between tillage and CC, and no significant tillage or CC effects on yield, implying that the yields were similar in the NT and ST plots (fig. 4). Unger and Baumhardt (1999) reported similar sorghum grain yield under NT and ST systems in Texas; however, our average yields were lower than reported average yields under irrigation (Steduto et al. 2012).

We speculate that heavy infestations of the sugarcane aphid (Melanaphis sacchari) and observed leaf stickiness late in the season explains the lower yields in 2017 (J. Dahlberg, personal communication). There was no water deficit condition in this study.

CCs had no effect on yield. In arid and semiarid regions, soil moisture depletion by CCs may adversely affect successive crops, particularly if the CCs are allowed to grow into periods of high ET. Previous determinations of soil water depletion of CCs during the same winter period in the SJV indicate relatively small differences - on the order of 2 inches - between cover cropped and bare soil conditions (Mitchell et al. 2015) in the same field with the same soil type. Residues from CCs may also hinder planting and stand establishment, but they did not affect yield here. Also, although the combination of CC and NT was reported previously to improve several soil properties, including water infiltration, aggregate stability (Mitchell et al. 2017) and soil water-holding capacity (Araya et al., unpublished data), we did not see any effect from the CC on sorghum yield.

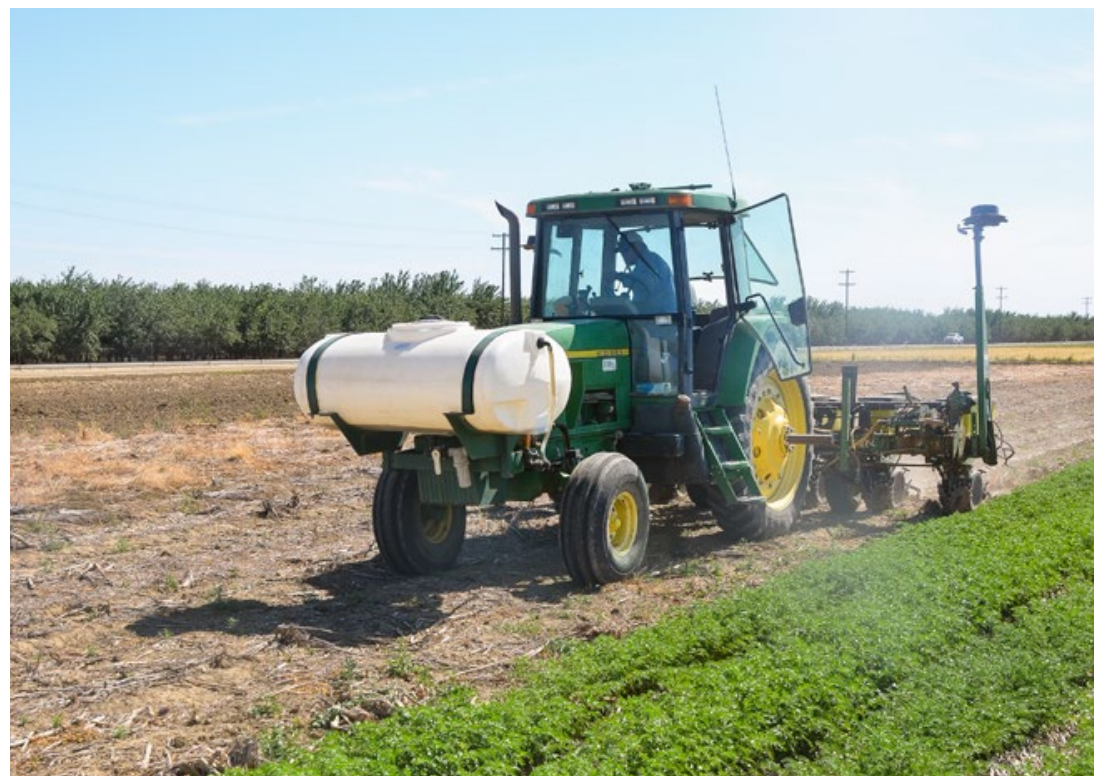

No-till sorghum seeding on May 22, 2017, into an NTNO (no-till, no cover crop) plot using a 6-row John Deere 1730 no-till seeder. On the lower right, there is an NTNO garbanzo plot. Photo: Jeffrey P. Mitchell.

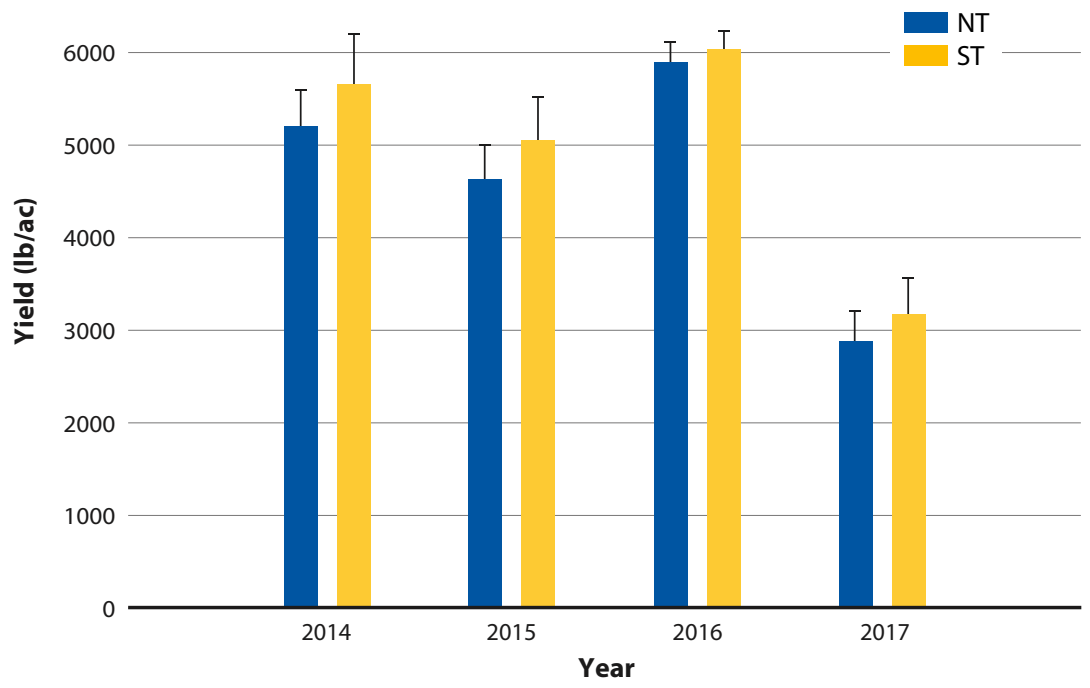

FIG. 4. Sorghum grain yields from 2014 to 2017. NT, no-tillage with and without a cover crop combined; ST, standard tillage with and without a cover crop combined. Data values show means and standard errors. For each year, there were no significant treatment effects or interactions.

\section{Garbanzo yields in NT higher than ST in two of four years}

In garbanzo, there was a highly significant year effect $(P<0.001)$, but no interactions between year and tillage $(P=0.17)$, year and CC $(P=0.31)$, tillage and CC $(P=$ $0.79)$, or year, tillage and CC $(P=0.81)$. When each year was analyzed individually, there were no significant $(P>0.05)$ interactions, and no significant CC effects. NT produced greater yields $(P<0.001)$ than ST in 2015 $(P=0.057), 2016(P<0.001)$ and in $2017(P=0.009)$

(fig. 5). Thus, compared to ST, NT matched garbanzo yields in 2018 and surpassed yields in 2015, 2016 and 2017. Averaged over the 4 years, garbanzo yields were 


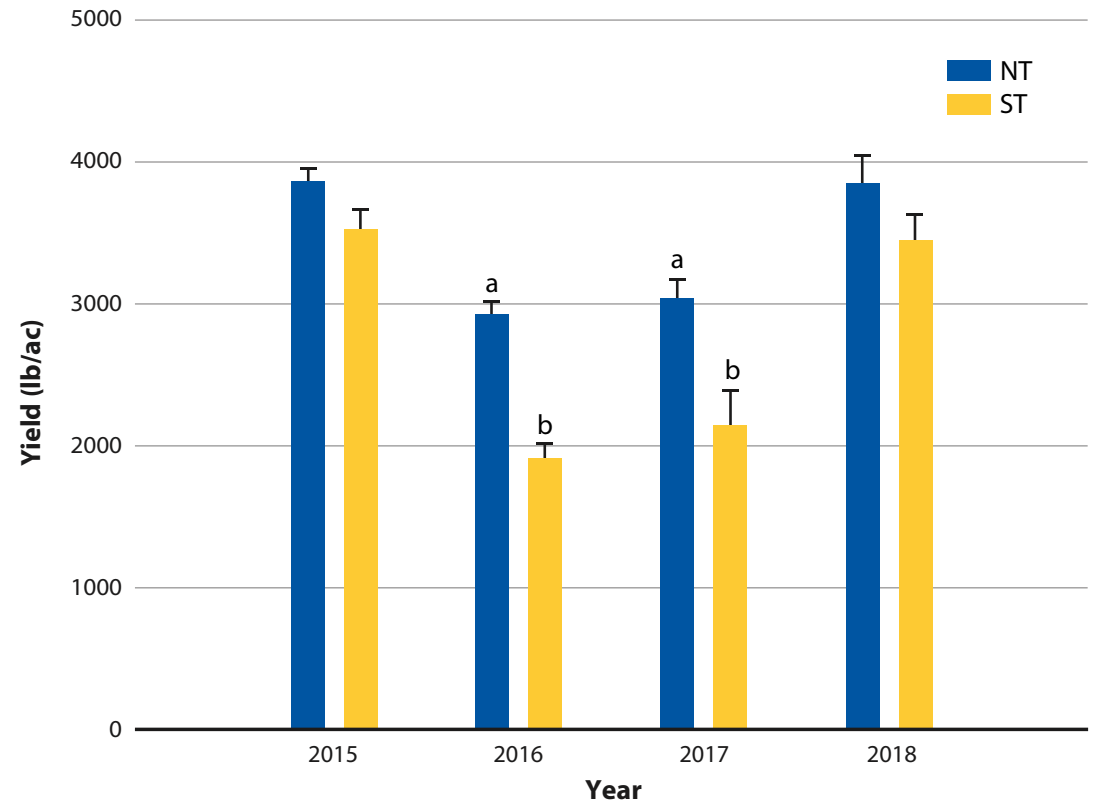

FIG. 5. Garbanzo yields from 2015 to 2018. NT, no-tillage with and without a cover crop combined; ST, standard tillage with and without a cover crop combined. Data values show means and standard errors. There were no significant treatment effects or interactions in 2015 and 2018. In 2016 and 2017, for each year separately, yields in NT were significantly greater than in ST. approximately $25 \%$ greater in the NT compared to the ST plots. Similar to sorghum, CC did not affect yield in any year.

\section{Inconclusive results on garbanzo growth in STCC plot}

Early crop stand establishment for both crops across all study years was similar in all treatments. In 2017, garbanzos in the STCC grew significantly less than in the NTNO, NTCC and STNO treatments (fig. 6; this was not observed in other years). To determine whether NT promotes garbanzo growth or the STCC in particular suppressed growth, we investigated whether a fungus was responsible for either decreased growth in the STCC or for enhanced growth in the other treatments. Based on symptoms in mid-May 2017, we initially postulated that a Fusarium spp. was a pathogen in the STCC. However, neither pathogenicity tests nor highthroughput DNA sequences from the elongation factor intron-rich region (data not shown) indicated that there was an important pathogenic Fusarium spp.

In contrast, the high-throughput ITS rDNA sequences were consistent with the presence of the fungal pathogen Macrophomina phaseolina in the field. In the vigorous plants that were sampled from the STCC plots, $11 \% \pm 5 \%$ of the sequences were M. phaseolina,

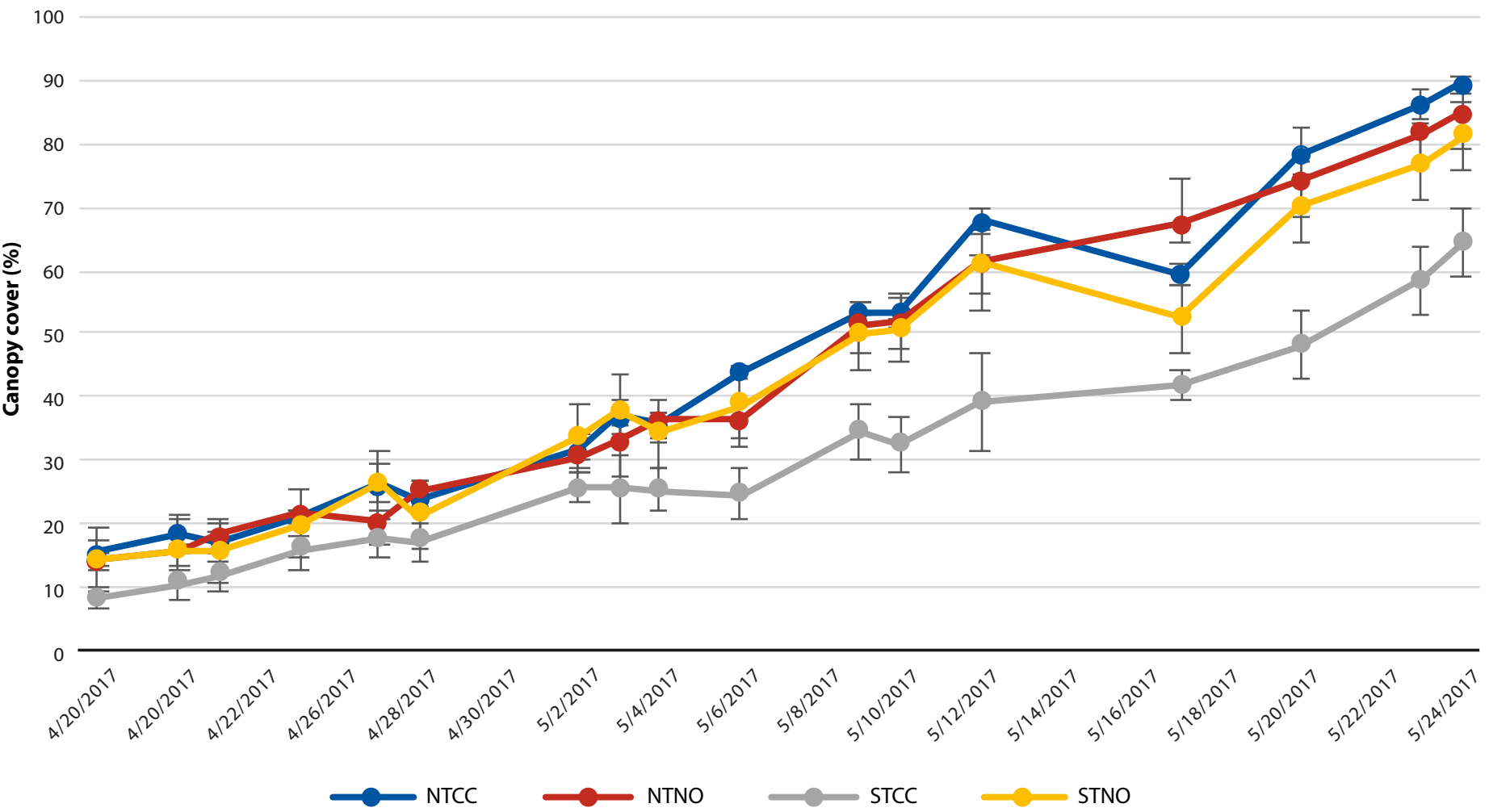

FIG. 6. Percent canopy cover for tillage and CC systems in garbanzo in 2017. NTCC, no-tillage and no cover crop; NTNO, no-tillage with no cover crop; STCC, standard tillage with cover crop; STNO, standard tillage no cover crop. An analysis of the slope of the linear regressions indicated that there was significantly less growth as measured by canopy cover in STCC than in the other treatments $(P=0.01)$, i.e., the CC under ST was harmful to garbanzo growth. 
but in the unthrifty plants, $26 \% \pm 18 \%$ of the sequences were M. phaseolina. Although we did not observe typical charcoal rot symptoms on roots in either 2017 or 2018 , in mid-June 2018, we incubated roots and soil in conditions that were suitable for diagnosis and quantification of microsclerotia of M. phaseolina. In 2018, there were significantly more $M$. phaseolina microsclerotia in the STNO treatments that had been in garbanzos in the previous year than in the NT plots. Although we did not observe any classic charcoal rot symptoms, when the garbanzo root segments were incubated at a temperature conducive for $M$. phaseolina, the pathogen was readily isolated. Thus, in accordance with Magyarosy et al. (1985), growers should monitor for $M$. phaseolina, which flourishes in warmer temperatures. Because all systems were irrigated similarly throughout the season, it is unlikely that drought - a known factor for increasing the risk of disease in garbanzos was the reason for lower growth in the STCC system. However, soils with high organic matter, such as perhaps the recently incorporated CC in the STCC system, are also known to increase risk of disease (Light 2018). A final possible explanation for the yield response of the STCC system in 2017 may have resulted from soil water deficit in the CC treatment; however, because rainfall during the winter of 2016-2017 was actually highest and above the 30 -year average, this is unlikely.

\section{NT may be a viable and water- efficient option for growing garbanzos and sorghum}

ST practices have been used throughout the SJV for nearly 90 years. Using similar inputs and amounts and pest management, we show that a garbanzo and sorghum rotation in NT yielded at least as well as in ST. In our trial, NT yielded an average of 3,417 lb/ac of garbonzos versus ST, which had an average of $2,738 \mathrm{lb} / \mathrm{ac}$. Garbanzo production in California, which is almost all in ST, averages 2,300 lb/ac (Long et al. 2019) statewide, with higher averages of 3,200 lb/ac typically reported in the SJV (L. Kubo, Rhode Stockton Bean LLC, Tracy, Calif., personal communication).

If water costs continue to rise as curtailments on water supply increase, the value of some agricultural land without allocations in California will eventually decline (Hanak et al. 2019), providing more of an economic incentive for using NT for growing a portfolio of crops, such as sorghum and garbanzo, somewhat more amenable to constraints on available water supplies. A review by Richter et al. (2017) of technically credible case studies that could help document the potential water savings attainable by using various strategies or technologies, including NT farming, found that reduced non-beneficial consumption derived from NT may increase water application efficiency and result in reductions in consumptive water use on the order of 3.5 inches per acre in a range of irrigation scenarios and locations compared to ST systems that do not have surface residues. While changes in soil function — including the increases in aggregation, water infiltration (Mitchell et al. 2017), porosity and water holding capacity (Araya 2019) that we documented in the NTCC system may take several years to be achieved, generating and preserving surface residues as a first step toward transforming annual cropping systems in the ways we describe here can be done in a few cropping cycles. For these reasons, this work may serve as a decision-making tool for growers who are considering producing garbanzos and grain sorghum in the future, especially if there is the opportunity to both reduce management costs and maintain yields (Mitchell et al. 2008; Mitchell et al. 2016; Mitchell, Shrestha, Munk 2016). CA
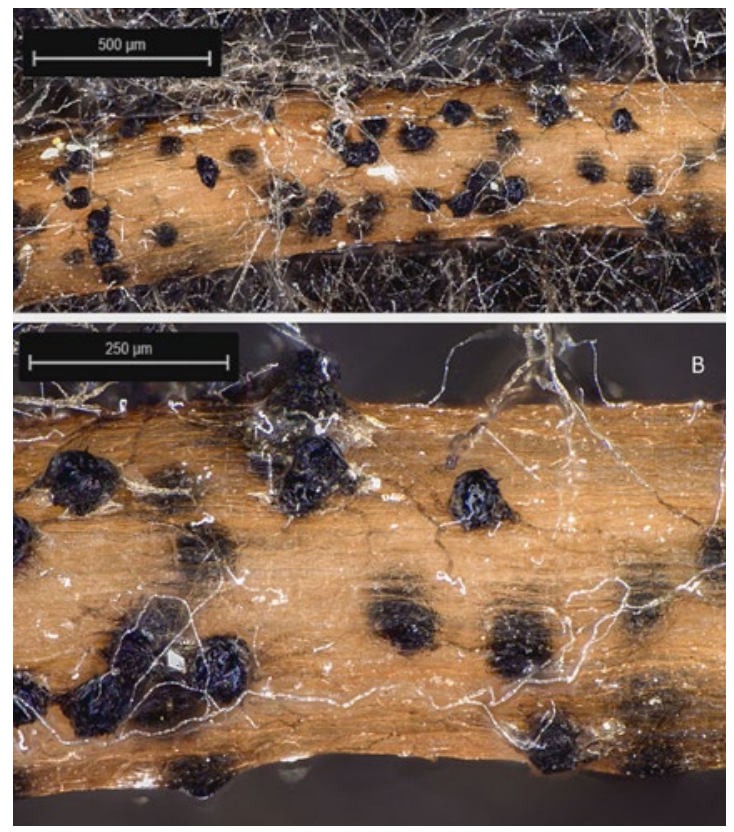

A segment of an asymptomatic garbanzo root from an infected plant was cultured. These are two magnified images; the size bar is approximately 0.02 inches in (A) and 0.01 inches in (B). The root was infected by the plant pathogenic fungus Macrophomina phaseolina, which produces dark, multi-celled microsclerotia, its survival structure. The thin filaments are the fungal hyphae. Photo: Lynn Epstein.
J.P. Mitchell is UC Cooperative Extension (UCCE) Cropping Systems Specialist, Department of Plant Sciences, UC Davis; A. Shrestha is Professor, California State University, Fresno; L. Epstein is Professor, Department of Plant Pathology, UC Davis; J.A. Dahlberg is Director, Kearney Agricultural Research and Extension Center, UC ANR, Parlier; T. Ghezzehei is Professor, School of Natural Resources, UC Merced; S. Araya is Postdoctoral Researcher, Earth Systems Science, Stanford University, Palo Alto; B. Richter is Executive Director, Sustainable Waters, Crozet, Va.; S. Kaur is Staff Research Associate and P. Henry is Graduate Student Researcher, Department of Plant Pathology, UC Davis; D.S. Munk is UCCE Advisor in Soils, Water and Cotton, Fresno County; S. Light is UCCE Advisor in Agronomy, Sutter County; M. Bottens is Farmer, Bottens Family Farm, Cambridge, III; and D. Zaccaria is UCCE Associate Specialist in Agricultural Water Management, UC Davis.

The authors sincerely thank Dr. Ted Hsiao - the most esteemed professor at UC Davis of this paper's first author, Jeff Mitchell — for his insights, guidance and information that have greatly helped our manuscript. 


\section{References}

Anderson R. 2011. Synergism: A rotation effect of improved growth efficiency. Adv Agron 112:205-23. https://doi. org/10.1016/B978-0-12-3855381.00005-6

Araya SN. 2019. Long-term impact of cover crop and reduced disturbance tillage on soil pore size and soil water storage. Ph.D. Dissertation. In partial fulfillment of degree requirements, Dept. of Life and Environmental Sciences, UC Merced.

Baker JB, Southard RJ, Mitchell JP. 2005. Agricultural dust production and composition in standard and conservation tillage systems in the San Joaquin Valley. J Environ Qual 34:1260-9. https://doi.org/10.2134/ jeq2003.0348

Berman H. 1994. Soil organic matter and available water capacity. J Soil Water Cons 49(2):189-94

Bettner T. 2012. California roundtable on water and food supply. From storage to retention. Expanding California' options for meeting its water needs. 14 p. https://aginnovations.org/ wp-content/ uploads/2019/07/CRWFS Storage_to_Retention.pd

[CDFA] California Department of Food and Agriculture. 2018. California Agricultural Statistics Review. 2017 - 2018. www.cdfa. ca.gov/statistics/PDFs/201718AgReport.pdf

Dumanski J, Reicosky DC, Peiretti RA. 2014b. Preface - Global pioneers in soil conservation: Common elements and lessons learned. Int Soil Water Cons Res 2(1):1-4. https://doi.org/10.1016/S20956339\%2815\%2930018-6

[DWR] California Department of Water Resources. 2014. Sustainable Groundwater Management Act. Division of Agriculture and Natural Resources. UC Davis. www.waterboards.ca.gov/ water_issues/programs/gmp/ docs/sgma/sgma_20190101. pdf (accessed Feb. 8, 2018).

DWR. 2018. Water Data Portfolios. California Water Plan Update. https://water.ca.gov/ Programs/California-Water-Plan/ Water-Portfolios (accessed Jan.y 24, 2021).

[FAOSTAT] Food and Agriculture Organization of the United Nations Statistics Division. FAOSTAT food and agriculture data (database). Accessed Sept. 5, 2019.
Franzluebbers A. 2010. Will we allow soil carbon to feed our needs? Carbon Manag 1(2):23751. https://doi.org/10.4155/ cmt.10.25

Hanak E, Escriva-Bou A, Gray B, et al. 2019. Water and the future of the San Joaquin Valley. Public Policy Institute of California. www.ppic.org/publication/ water-and-the-future-of-thesan-joaquin-valley/

Hanson BR, May DM. 2005. Crop coefficients for dripirrigated processing tomatoes. Agric Water Manag 81:381-99. https://doi.org/10.1016/j.agwat.2005.04.007

Hanson BR, May DM. 2006. New crop coefficients developed for high-yield processing tomatoes. Calif Agr 60(2):95-9. https://doi. org/10.3733/ca.v060n02p95

Johnson Hake S, Grimes DW, Hake KD, et al. 1996. Irrigation scheduling. In Cotton Production Manual. University of California Division of Agriculture and Natural Resources Publication 3352. 442 p. ISBN-13: 978-1879906-09-9

Kelly C, Fonte S, Shrestha A, et al. 2021.Winter cover crops and no-tillage promote soi macrofauna communities in irrigated, Mediterranean crop land in California. Appl Soil Ecol 166:104068. https:// doi.org//10.1016/j.apsoil.2021.104068

Klocke NL, Currie RS, Aiken RM. 2009. Soil water evaporation and crop residues. T ASBE 52(1):103-10. https://doi. org/10.13031/2013.25951

Lindwall CW, Sonntag B. 2010. Landscapes transformed: The history of conservation tillage and direct seeding. Canada: Knowledge Impact in Society Project. ISBN: 978-0-9812843-1-6.

inquist $B$, Snyder R, Anderson F et al. 2015. Water balances and evapotranspiration in waterand dry-seeded rice systems. Irrig Sci 33:375-85. https://doi. org/10.1007/s00271-015-0474-4

Long R, Leinfelder-Miles M, Mathesius K, et al. 2019. Garbanzo bean (chickpea) production in California. UC ANR Publication 8634.18 p. ISBN-13: 978-1-62711-078-5. https://doi. org/10.3733/ucanr.8634

Lundy M. 2015. Managing irrigated corn during drought. UC ANR Publication 8551.5 p. ISBN13: 978-1-60107-949-7. https:// doi.org/10.3733/ucanr.8551
Madden NM, Southard R Mitchell JP. 2008. Conservation tillage reduced PM10 emissions in dairy forage rotations. Atmos Environ 42.3795-3808. https://doi.org/10.1016/j.atmosenv.2007.12.058

Magyarosy A, Hoover R, Hancock J. 1985. Charcoal root rot limits potential of chickpea in the Central Valley. Calif Agr 39(3):11

Mitchell JP, Carter L, Munk D, et al. 2012. Conservation tillage systems for cotton advance in the San Joaquin Valley. Calif Agr 66(3):108-15. https://doi. org/10.3733/ca.v066n03p108

Mitchell JP, Reicosky DC, Kueneman EA, et al. 2019. Conservation agriculture systems. CAB Reviews 14(1). 25 p. www.cabi.org/cabireviews / review/20193184383

Mitchell JP, Shrestha A, Dahlberg JA, et al. 2016. Prospect of no-till planting of sorghum with and without cover cropping in the San Joaquin Valley. Crop Forage Turfgrass Manag 2:1-3. https://doi.org/10.2134/ cftm2015.0208

Mitchell JP, Shrestha A, Irmak S. 2015. Trade-offs between winter cover crop production and soil water depletion in the San Joaquin Valley, California. J Soil Water Cons 70(6):430-40. https:// doi.org/10.2489/jswc.70.6.430

Mitchell JP, Shrestha A, Mathesius K, et al. 2017. Cover cropping and no-tillage improve soil health in an arid irrigated cropping system in California's San Joaquin Valley, USA. Soil Tillage Res 165:325-35. https://do org/10.1016/..still.2016.09.001

Mitchell JP, Shrestha A, Munk DS. 2016. Cotton response to long-term no-tillage and cover cropping in the San Joaquin Valley. J Cotton Sci 20:8-17. www. cotton.org/journal/2016-20/1/ upload/JCS20-008.pdf

Mitchell JP, Singh PN, Wallender WW, et al. 2012. No-tillage and high-residue practices reduce soil water evaporation. Calif Agr 66(2):55-61. https://do org/10.3733/ca.v066n02p55

Mitchell JP, Southard RJ, Madden NM, et al. 2008. Transition to conservation tillage evaluated in San Joaquin Valley cotton and tomato rotations. Calif Agr 62:74-9. https://doi. org/10.3733/ca.v062n02p74

Papavizas GC, Klag NG. 1975. Macrophomina phaseolina from soil. Phytopathology 65:182-7.
Pryor R. 2004. Switching to no-till can save irrigation water. Univ. Nebraska Lincoln Ext. Pub. EC 196-3. https://extension.unl. edu/statewide/saline/SWITCH ING\%20TO\%20NO-TILL\%20 CAN\%20SAVE\%20IRRIGATION\%20WATER.pdf

Richter BD, Brown JD, DiBenedetto $R$, et al. 2017. Opportunities for saving and reallocating agricultural water to alleviate scarcity. Water Policy 19(5):886907. https://doi.org/10.2166/ wp.2017.143

Schmidt R, Gravuer K, Bossange AV, et al. 2018. Long-term use of cover crops and no-till shift soil microbial community life strategies in agricultural soil. PLOS ONE 13(2):e0192953. https://doi.org/10.1371/journal. pone.0192953

Sposito G. 2013. Green water and global food security. Vadose Zone J. Special Section VZJ Anniversary Issue. p 1-6. https://doi.org/10.2136/ vzj2013.02.0041

Steduto P, Hsiao TC, Fereres E, Raes D. 2012. Crop yield response to water. FAO Irrigation and Drainage Paper 66. ISSN0254-5284

Strand LL. 2000. Integrated Pest Management for Small Grains. University of California Statewide Integrated Pest Management Project. Publication 3333. 126 p. ISBN-13: 978-0931876-91-2

[SWEEP] State Water Efficiency Enhancement Program. 2019. California Department of Food and Agriculture, Sacramento, CA. www.cdfa.ca.gov/oefi/ sweep/

Udall B, Overpeck J. 2017. The twenty-first century Colorado River hot drought and implications for the future. Wate Resour Res 53:2404-18.

Unger PW. 1984. Tillage and residue effects on wheat, sorghum, and sunflower grown in rotation. SSSAJ 48(4):885-91.

Unger PW, Baumhardt RJ. 1999. Factors related to dryland grain sorghum yield increases 1939 through 1997. Agron J 91:8705. https://doi.org/10.2134/ agronj1999.915870x

Unger PW, Parker JJ. 1976. Evaporation reduction from soil with wheat, sorghum and cotton residues. Soil Sci Soc Am J 40(6):938-42. https://doi.org/10.2136/sssaj1976.0361599500400006 $0035 x$

van Donk SJ, Martin DL, Irmak S, et al. 2010. Crop residue cover effects on evaporation, soil water content, and yield of deficit-irrigated corn in west-central Nebraska. T ASABE 53(6):1787-97. https://doi. 